\title{
POLISH-UKRAINIAN MILITARY UNITS IN THE YEARS 1991-2018
}

\author{
Lt. Col. Marek ŻYŁA, PhD \\ m.zyla@akademia.mil.pl \\ War Studies University, Warsaw, Poland \\ Faculty of Military Studies
}

\begin{abstract}
The history and traditions of Polish-Ukrainian military contacts are as rich as the relations between the two nations. Intensive military cooperation dates back to the mid-16th century and is connected with the pursuit of the military capabilities of the Cossacks. The next chapter of Polish-Ukrainian military cooperation started just after the end of the First World War. The state authorities, analysing the political and military situation, noticed the importance of Ukraine for the future balance of power in Europe and its impact on Poland's security in the east. The leader of the Ukrainian National Republic (UNR), ataman Symon Petlura, had a similar approach. The need for joint action in the face of growing threat led both parties to intensify negotiations and to sign a political and military agreement.

The findings made on 14 January 1992 during the visit of the Minister of Defence of Ukraine, Colonel Konstantin Morozov, to Poland should be regarded as the beginning of contemporary military contacts with Ukraine. In formal terms, the legal basis for cooperation was the agreement on this matter, signed on 3 February 1993 in Kiev. In its framework, both parties agreed to develop, inter alia, training and training-operational cooperation. It was intended to be implemented through contacts between units stationed in the border regions, transferring the main effort to the lower levels of command.
\end{abstract}

Keywords: military cooperation, joint military units, peacekeeping missions, stabilisation missions 


\section{Introduction}

In contemporary international relations, in addition to international political, economic, cultural and environmental cooperation, military cooperation is increasingly being undertaken. An invitation to "joint military discussions" brings armies together, at the same time giving them the opportunity to get to know each other. Military cooperation makes it possible to compare the structural composition of the armed forces, training processes and military equipment, and to exchange training experience. It is also an opportunity to get acquainted with the latest trends in the development of combat technology and to start cooperation in this area. The element combining most forms of military cooperation is multinational military units. In connection with the above, the basic goal of the article is a systematic analysis of Polish-Ukrainian military cooperation after 1991 in the field of forming joint military units.

The history and traditions of Polish-Ukrainian military contacts are as rich as the relations between the two nations. Intensive military cooperation dates back to the mid-16th century. It was based on efforts to improve the military capabilities of the Cossacks, the paramilitary form of self-organisation in society, in order to strengthen the security of the south-eastern borders of the Polish state. The next chapter of the Polish-Ukrainian military cooperation started just after the end of the First World War. After Poland regained independence, it was hoped to forcefully resolve the issue of the course of future borders. The state authorities, analysing the political and military situation, noticed the importance of Ukraine from the very beginning for the future balance of power in Europe and its influence on the security of Poland in the east. This was particularly important in the context of the growing threat from Bolshevik Russia. The leader of the Ukrainian National Republic (UNR), ataman Symon Petlura, had a similar approach. The need for joint action in face of the growing threat led both parties to intensify negotiations and to sign a political and military agreement.

The findings made on 14 January 1992 during the visit to Poland of the Minister of Defence of Ukraine, Colonel General Konstantin Morozov, should be regarded as the beginning of military contacts with independent Ukraine. In formal terms, the legal basis for cooperation was the Agreement between the Minister of National Defence of the Republic of Poland and the Minister of Defence of Ukraine 
on cooperation in the military field ${ }^{1}$. Both parties agreed to develop training and training-operational cooperation (AMON ref. 2093/03/27, pp. 82-84). The intention was to carry it out through contacts between units stationed in border regions, and to shift the main burden of cooperation to the lower levels of command. The border contacts were initiated in June 1994 by the visit of the Ukrainian command of the Carpathian Military District (CMD, Polish - PkWO) to the units of the Krakow Military District (KMD,Polish - KMO). The Ukrainian delegation expressed its interest in the idea of cooperation at lower command levels and participation in exercises with the army (AMON ref. 1668/2000/7, pp. 41-42).

\section{Polish-Ukrainian Peace Force Battalion}

The vision of participation in peacekeeping operations with NATO soldiers and the possibility of bilateral cooperation within the framework of the Partnership for Peace programme contributed to the commencement of Polish-Ukrainian talks on the formation of a joint subdivision. The political will of both parties, especially the direct involvement of the presidents in the project, accelerated the process of its formation. The idea of creating a joint unit was born in June 1995 during the Undersecretary of State Andrzej Ananicz's visit to the Chancellery of the President of the Republic of Poland in Kiev (Chojnowski 1996, p. 136). The idea of establishing a Polish-Ukrainian battalion was established during the meeting of defence ministers in October 1995 in Solina (AMON ref. 2026/03/95, p. 166), and in November 1995 military experts began their work (AMON ref. 2027/03/6, pp. 43-45). The initial structure of the sub-unit was analysed at the meeting of the commanders of military districts (MD, Polish - OW) in February 1996 in Lviv (AMON ref. 2027/03/3, pp. 335-338). At the next meeting in June 1996, in Kraków, another draft of the structure and dates of the first training courses were agreed. During the meeting in Lviv in July 1996, the general structure of the common battalion was approved (AMON ref. 2027/03/3, pp. 303-306).

1 Signed in Kiev on 3 February 1993 in Polish and Ukrainian language versions. 
The protracted process of forming a joint unit did not prevent the training of subdivisions to be included in its composition (AMON ref. 2111/03/17, p. 90). The terms of reference completed in the first half of 1996 indicated that the deadlines set so far would not be met. Despite prioritising the project and the attempts to accelerate the work related to its implementation, the achievement of the initial readiness by the battalion was postponed from 1 January 1997 to the middle of the year (Chojnowski 1997, p. 143). A different perception of the process of forming a battalion by the Ukrainian side, which saw it as an element of cross-border cooperation, led to significant delays (AMON ref. 2111/03/17, pp. 73-74).

The legal and international basis for the formation of POLUKRBAT was the bilateral Agreement of 26 November 1997 on the Establishment of a Joint Military Unit (Dz.U. z 2003, nr 78, poz. 692). The formation of the Polish part of the subdivision (PKW w sktadzie polsko-ukraińskiego... 2000) was completed by April 1998. Next year, POLUKRBAT became operational (Drzewicki 2011, p. 160). Finally, the subdivision was formed on the basis of: in the case of the Polish side - the $4^{\text {th }}$ Mechanised Brigade of the $14^{\text {th }}$ Armoured Battalion from Przemyśl, and in the case of the Ukrainian side - the $208^{\text {th }}$ Mechanised Brigade of the $310^{\text {th }}$ Armoured Regiment (24 $4^{\text {th }}$ Iron Mechanised Division) from Yavoriv. The headquarters were located in the garrison of Przemyśl. In accordance with its tenure, Poland assigned: the headquarters, staff, two mechanised companies, the command company and the logistics company (Fig. 1). The Ukrainian side assigned: staff personnel, two mechanised companies and components for the command and logistics company. The total number of posts in the battalion was 753, including 192 professional soldiers and 561 basic military service posts. The Ukrainians had 363 posts to fill, including 94 for professional soldiers (48 officers, 26 chief warrant officers, 20 non-coms). The official language was English. 


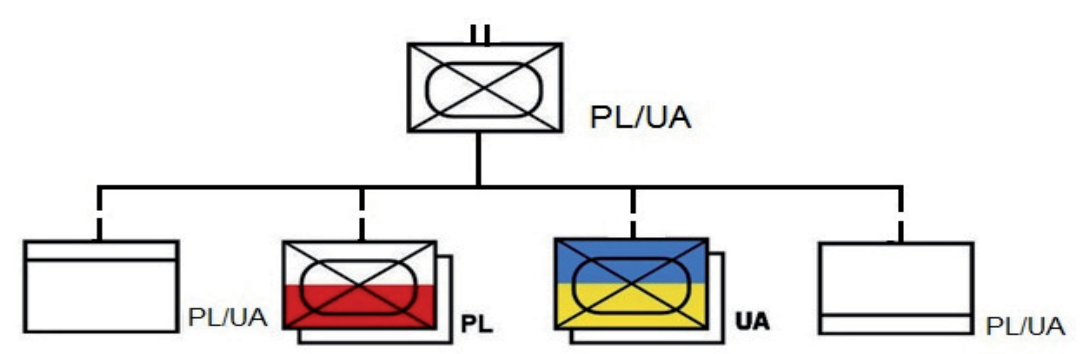

Source: Own study based on: (PKW w składzie polsko-ukraińskiego batalionu w siłach międzynarodowych w Kosowie 2000).

Fig. 1. Organisational structure of the Polish-Ukrainian Peace Force Battalion

The first operation of the battalion as a close-formation subdivision took part in manoeuvres as part of "Shield for Peace 98 (Polish - Tarcza Pokoju 98)" at the Yavoriv training ground (Kronika stosunków międzynarodowych... 1999, p. 318). Practical action was not hampered by the fact that the parties had not ratified the Agreement on the Establishment of a Joint Unit (Cieślik 1999, p. 180). The issue of ratification was raised in 1999 by the Council of Ministers of the Republic of Poland in its Resolution No. 17/99 (Uchwata Nr 17/99... 1999). The consent for ratification of the agreement by the President of the Republic of Poland was given in a manner that did not require prior consent to be granted by t law. The President ratified it on 20 April 1999, and the Supreme Council of Ukraine did the same on 6 April 2000 (Polsko-Ukraiński Batalion... 2018). The Polish-Ukrainian subdivision in terms of its training and, what was equally important in the case of this initiative, in terms of politics, enjoyed the recognition of its superiors and considerable media interest. During its operation, it received several distinctions and honorary titles. The most important of these were (Szumański 2008, p. 288):

- Exemplary subdivision of the 2nd Air-Mechanised Corps;

- Exemplary subdivision of the 2nd Mechanised Corps;

- Honorary Badge of the Armed Forces of the Republic of Poland (awarded by the President of the Republic of Poland);

- Award of Polish-Ukrainian Reconciliation (awarded by the Chapter of PolishUkrainian Reconciliation). 
In 2010, due to the possibilities of cooperation ceasing in their current form and the need for their structural extension, the Polish subdivision was disassembled (21 Brygada Strzelców... 2018).

\section{Lithuanian-Polish-Ukrainian multinational brigade}

The next stage of direct military cooperation with Ukraine was to form a Lithuanian-Polish-Ukrainian battalion of peacekeeping forces. Lithuania put forward a political initiative for the creation of the unit in 2005. (Informacja $n t$. tworzenia... 2007). This idea was re-launched in June 2007 with the decision by the Defence Ministers of the countries concerned to start work on its formation. The aim of the trilateral battalion was to strengthen the cooperation of the armed forces, deepen mutual trust, strive to strengthen regional security and support the Euro-Atlantic aspirations of Ukraine. The reasons for establishing cooperation in this format were the previous effects and experiences related to the bilateral cooperation of Ukraine and Poland within POLUKRBAT, and Poland and Lithuania within LITPOLBAT ${ }^{2}$, as well as the participation of the 30-person Lithuanian platoon in the mission carried out by POLUKRBAT KFOR. In autumn 2008, Defence Ministers decided to increase the combat capacity of the joint unit to the level of a brigade. The change of concept resulted in the simultaneous suspension, in December 2008, of work on the creation of the battalion and the commencement of the process of forming the tri-national brigade (AMON ref. 2399/09/58, p. 49).

The conceptual work carried out in 2009 led to a preliminary determination of the structural and functional form of the brigade (Brygada Litewsko-Polsko...

2 LITPOLBAT - Lithuanian-Polish Peace Force Battalion; it functioned on the basis of the Agreement between the Government of the Republic of Poland and the Government of the Republic of Lithuania on the Establishment of a Joint Military Unit for the Maintenance and Restoration of International Peace and Security of 25 June 1997) and the Agreement between the Minister of National Defence of the Republic of Poland and the Minister of National Defence of the Republic of Lithuania on a Joint Military Peace Battalion of 14 April 1999. In accordance with Decision No. Z-95/Org/P1 of the Minister of National Defence of 21 December 2007, the Polish component of the Lithuanian-Polish Peace Force Battalion was disassembled on 30 June 2008. 
2009). At the beginning of the second half of the year, the Ministry of National Defence developed the Concept for the establishment of the Lithuanian-PolishUkrainian Brigade (LITPOLUKRBRIG) and sent it to the interested parties for consultation (Projekt Koncepcji utworzenia... 2009). The name of the unit was treated as temporary due to the open membership formula. The letter of intent for the establishment of the Brigade was signed on 16 November 2009 at the NATO Headquarters in Brussels (Adamski 2010, p. 160). In line with current standards, stakeholders committed themselves to signing an inter-state agreement and a technical agreement on the subject by the end of 2011. The primary objective for establishing the brigade was in line with the parties' intentions drawn up in the course of forming the tri-lateral battalion (List intencyjny w sprawie... 2018). In setting up the Brigade, it was assumed that peacekeeping operations under the auspices of international organisations would be the subject of the brigade's activities, in particular: the UN, NATO and the EU. In addition, it will be able to operate within temporary coalitions in accordance with the provisions of the Charter of the United Nations. On 10 February 2010, the Minister of National Defence of the Republic of Poland signed the decision to establish the Polish part of the Multinational Brigade Command and the Polish part of the Brigade Command Battalion (Wielonarodowa Brygada... 2018). The brigade was expected to reach operational capabilities in 2013 and to participate in peacekeeping missions as originally intended. After the presidential elections in Ukraine in 2010, activities related to the formation of the unit took on a largely declarative character. Up to 2013, these projects, with the exception of those related to the Polish component, were not put into practice.

The process of forming LITPOLUKRBRIG resumed in 2014. Under the influence of the ever-increasing threat from Russia, the new Ukrainian authorities have intensified their efforts to create a common unit. The defence ministers of the countries concerned signed the Agreement on the Creation of a Joint Tri-national Brigade on 19 September 2014. According to the Agreement, the brigade is capable of carrying out military operations on its own or of participating in them, and it is a multinational unit with the operational capabilities of a general-military brigade. On 16 January 2015, the Polish government adopted a draft Act on the Ratification of the tri-lateral Agreement, and it was submitted to the Sejm on 6 February (89. posiedzenie Sejmu... 2018). The Sejm passed the law on 20 March 2015, and it was signed by the President on 2 May 2015 (Prezydent podpisat 
ustawe... 2018). The last formal and legal stage on the way to the formation of LITPOLUKRBRYG was the ministerial technical agreement, which was signed on 24 July 2015 in Lviv (Dz.U. z 2015 r., nr 0, poz. 1291). The agreement clarifies the details related to the formation and functioning of the unit (Wspólna brygada Polski... 2018). The parties to the agreement also undertook to draw up a Joint Declaration of Requirements which would include a catalogue of the military capabilities of the Brigade Command, its structure and a list of the subordinate national components.

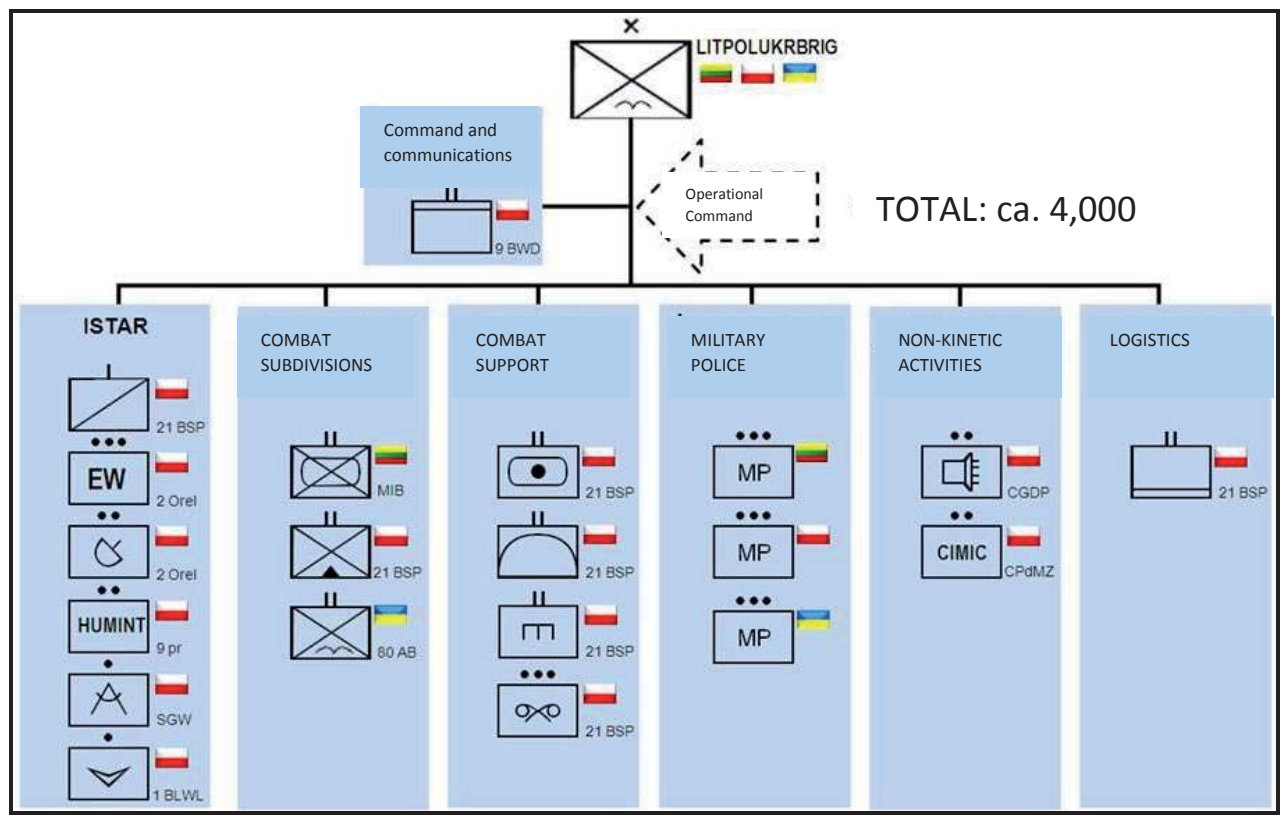

Source: LITPOLUKRBRIG. Jednostki afiliowane (n.d.)

\section{Fig. 2. LITPOLUKRBRIG structure}

On 25 January 2016, the Ministers of Defence of Lithuania, Poland and Ukraine took part in the official ceremony of the launch of the LITPOLUKRGRIG Multinational Brigade in Lublin (Brygada międzynarodowa sygnatem... 2018). The brigade initially became operational on 25 January 2016 and fully operational in early 2017. Its national components are stationed at permanent dislocation sites and will be deployed, on an ad hoc basis, in part or in full, for the purpose of conducting joint exercises or a peacekeeping mission. In structural terms, the brigade consists of an international command and command battalion, 
national subdivisions and personnel assigned to special purpose units (Fig. 2) (LITPOLBRIG. Historia... 2018). The brigade command is organised in accordance with NATO standards (Figure 3). The following subdivisions were assigned to the brigade: Duchess Birutë Uhlan Battalion (Lithuania), the $5^{\text {th }}$ Podhale Rifles Battalion (Poland), the $14^{\text {th }}$ Self-propelled Artillery Division (Poland), the $21^{\text {st }}$ Anti-Aircraft Artillery Division (Poland), the $21^{\text {st }}$ Logistic Battalion (Poland), the $16^{\text {th }}$ Sapper Division (Poland) and the $1^{\text {st }}$ Air-Manoeuvre Battalion (Ukraine). This structure also includes specialist subdivisions. The main task for which the brigade is preparing is the ability to counteract threats related to the conduct of peace support operations and crisis response operations (LITPOLUKRBRIG. Szkolenie... 2018). In terms of training, this means unifying the efforts of the affiliated components for proper cooperation with the Brigade Command, and from the Brigade Command's point of view, efficient and effective command of the subordinated components. Training activities are based on NATO and UN standards for peace support and crisis management. Due to the international character of the unit, tasks that include interoperability are also performed.

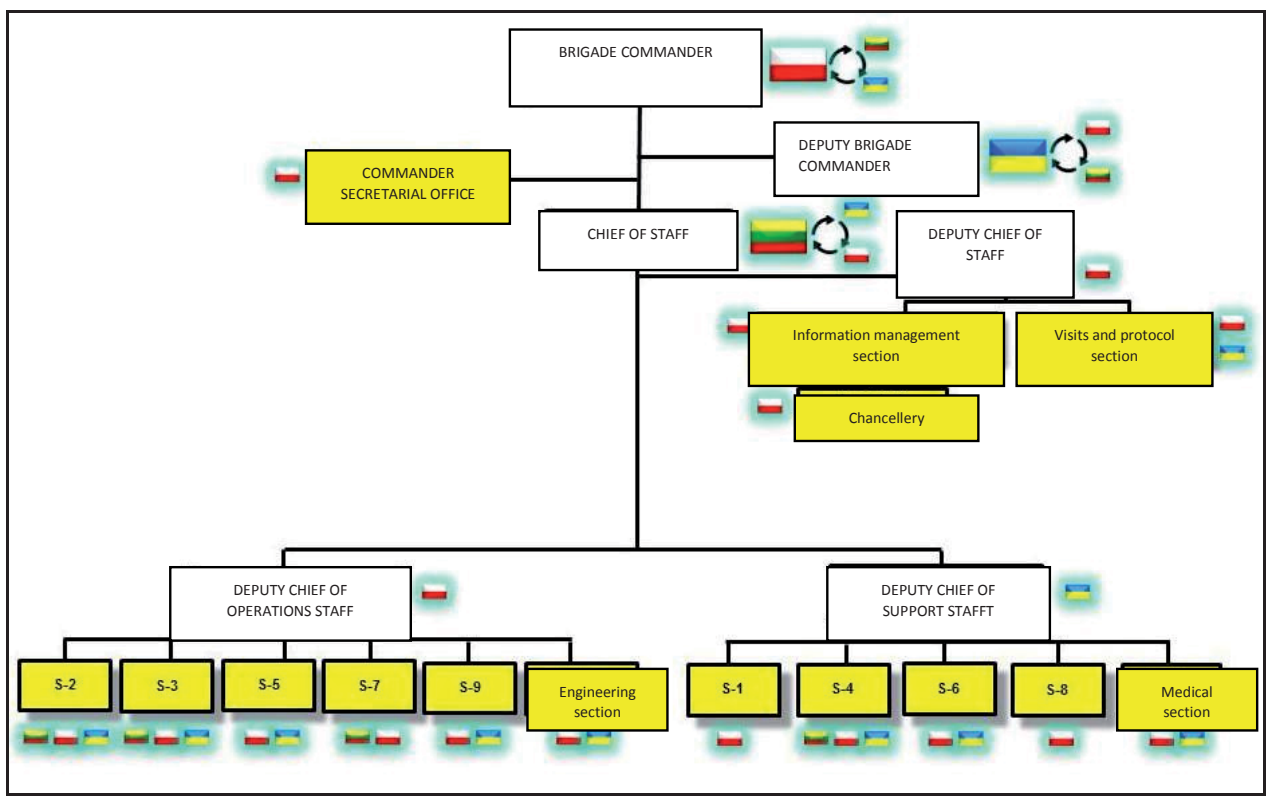

Source: LITPOLUKRBRIG. Struktura (n.d.)

Fig. 3. Organisational structure of LITPOLUKRBRIG Command 


\section{POLUKRBAT KFOR}

A joint Polish-Ukrainian unit within the framework of structures implementing peacekeeping missions was formed for the first time in Kosovo. On its territory, in the eastern (American) sector, a Polish Military Unit (PMU, Polish - PJW) was stationed from June 1999. It was a part of the Kosovo Force (KFOR) operating under the auspices of NATO (Kochanowski 2000, p. 307). From November 1999, in the area PJW KFOR was responsible for, the 37th Ukrainian infantry company, consisting of 108 soldiers, joined the mandated tasks (Szmyd 2000, p. 187). The subdivision, as far as operational subjugation is concerned, was placed under the command of the Polish contingent commander. After being subordinated to PJW, KFOR performed the same tasks as Poland.

Further developments in Kosovo led to the need for a long-term international presence. The long-lasting operation made it possible to use the formula of a common battalion in practice. In June 1999, the Minister of Defence of Ukraine took such an initiative (Meszka 2017, p. 10). Structural and organisational projects related to the allocation of national contingents lasted until the end of the first half of 2000. They were carried out at the level of the land troops of the states concerned. During a working meeting on 22 March 2000 in Rzeszow, Defence Ministers signed a Memorandum on the Extension of Cooperation with Regard to Participation in International Peacekeeping Missions (MEMORANDUM wsprawie... 2000). Its arrangements became effective after the technical agreement signed on 7 June 2000 had come into force. They concerned the composition of national contingents and the tasks and organisation of cooperation. The parties implemented redeployment of forces and resources to the mission area on their own. The national contingents were subordinated to the command of NATO until they entered the operational area of destination. In the mission area, the Ukrainian contingent was commanded by the battalion commander appointed by the Polish side, and the Ukrainian side appointed his deputy. The battalion commander and his deputy also served as national military contingent commander. When they had entered the mission area, the combined contingents, under the official name of POLUKRBAT KFOR (Figure 4), began to fulfil their mandate. Logistics security was implemented in the national system. 


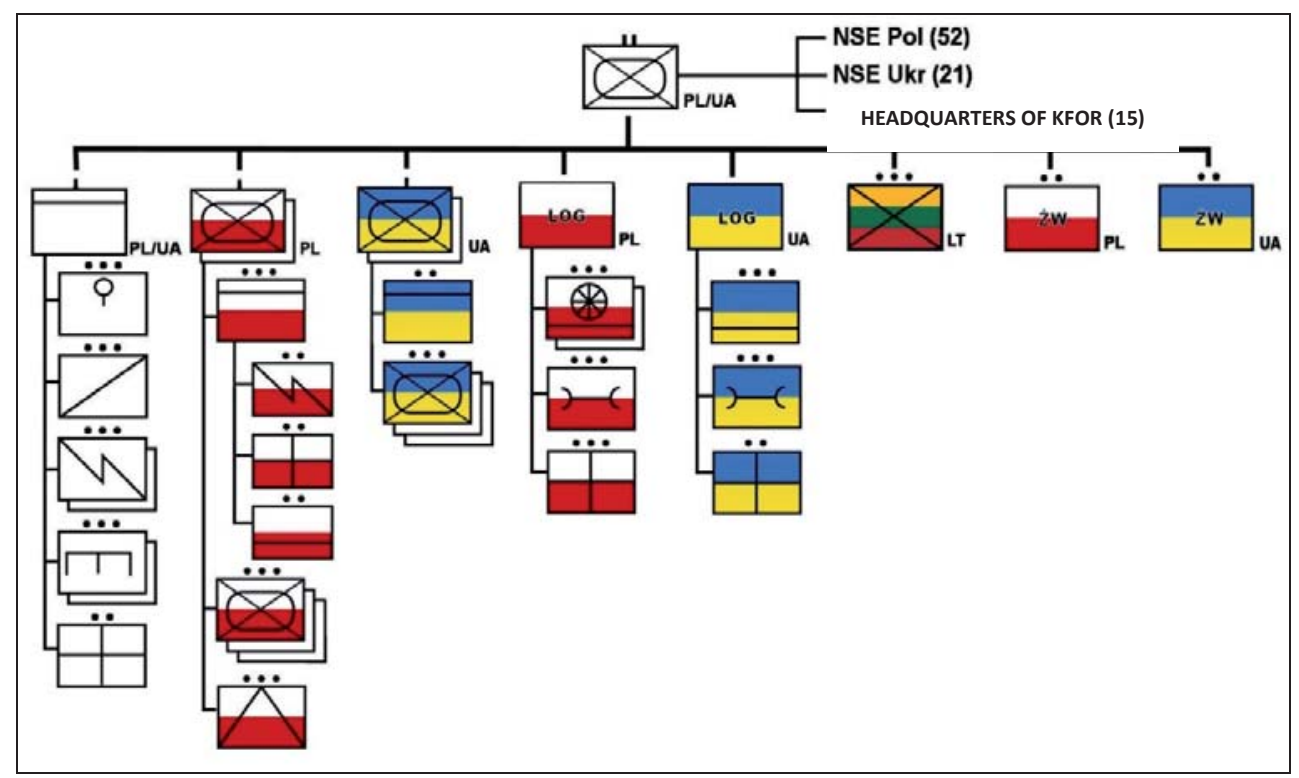

Source: Own study based on: (PKW w składzie polsko-ukraińskiego batalionu w siłach międzynarodowych w Kosowie 2000).

\section{Fig. 4. Organisational structure of POLUKRBAT KFOR}

Once again, the legislative process failed to keep pace with the practical dimension of cooperation. The agreement on POLUKRBAT's participation in the Kosovo mission as a unified common structure was not ratified. As a result, national contingents were sent to the operation area, as agreed by the ministers. The battalion, created on the basis of separate national contingents, entered into operation for the first time in mid-July 2000. It replaced the subdivisions of the 6th Airborne Brigade of the Armed Forces supported by the Ukrainian component (Nawrot 2001, pp. 157-158). Apart from Polish and Ukrainian soldiers, it also included the Lithuanian platoon. After the merger, the battalion consisted of a total of 767 soldiers, including 488 Poles, 249 Ukrainians and 30 Lithuanians. The National Support Components for the battalion were composed of 52 Polish and 21 Ukrainian soldiers. In addition, 15 soldiers were allocated to KFOR headquarters. The joint unit was a part of the Multinational Brigade - East (MNB-E), which was transformed into the Multinational Task Force - East (AMF-E) in 2005. 
POLUKRBAT KFOR was deployed in the eastern U.S. sector and a responsibility zone was allocated around Strpce, Kacanik, Drajoovice, Globocica and Urosevac (Fig. 5) (Drzewicki 2008, p. 240). The Polish-Ukrainian unit quickly gained the recognition of its superiors. The soldiers' combat training was appreciated, as well as their discipline, commitment and ability to cooperate in a multinational dimension. The main tasks of the contingent were to monitor compliance with the international provisions imposed on the sides of the conflict, to support humanitarian aid organisations, to secure convoys and to confiscate illegally owned weapons and military equipment.

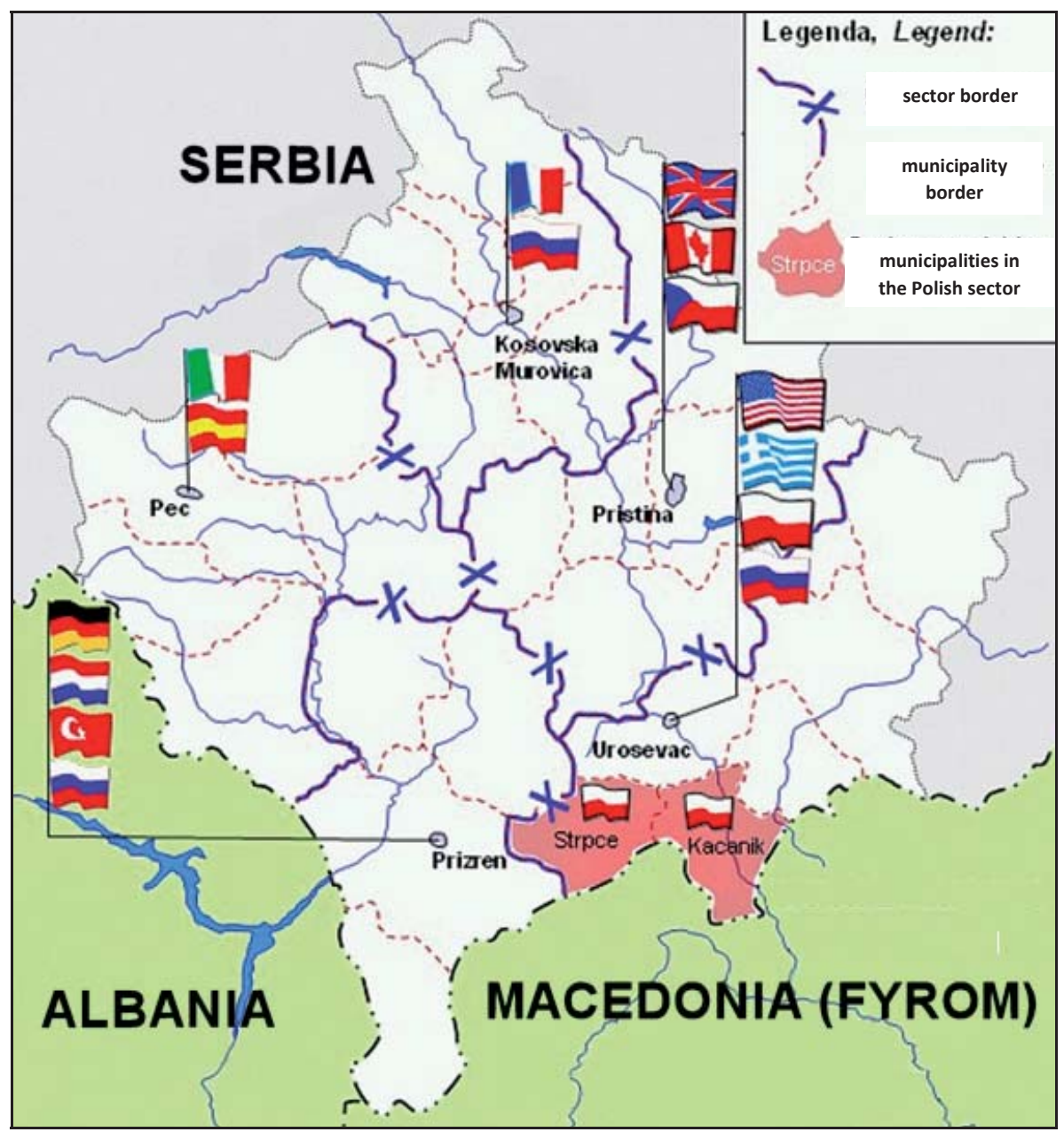

Source: Own study based on: Stowarzyszenie Kombatantów Misji Pokojowych ONZ (n.d.)

Figure 5. Location of KFOR in Kosovo 
The situation in Kosovo, which has stabilised from year to year, has allowed a gradual reduction in the staffing levels of the mission. In 2004, as a result of the general reduction of the International Forces in Kosovo, the number of POLUKRBAT KFOR, National Support Components and soldiers allocated to the Headquarters was reduced (Informacja $n t$. udziatu... 2004). The Polish contingent was reduced to 314, and the Ukrainian contingent to 288 soldiers (during the mission, the number of Ukrainian soldiers increased in comparison to the original state). Systematic improvement of security and striving for reduction of mission participants (AMON ref. 3018/13/9, pp. 18-19) created the premise for taking further action aimed at further reduction of POLUKRBAT KFOR in 2006 (AMON ref. 3018/13/9, pp. 26-29). According to the Concept for further engagement of PKW KFOR in the Kosovo Operation, developed by the Polish Operational Command, it was assumed that the nature of the tasks would change (Koncepcja dalszego zaangażowania... 2006). Deterioration of the internal situation in Kosovo due to the Albanian desire to establish their own statehood reduced and slowed down the pace of the planned reduction of the forces and temporarily prevented the change of status of the mission. At the end of 2007, there were 295 Polish and 179 Ukrainian soldiers serving in POLUKRBAT KFOR (AMON ref. 2840/11/7, pp. 22-23).

The improvement of the security situation in Kosovo and in the entire Balkan region led, in mid-2009, to the ministers of defence of NATO taking the decision to start a gradual reduction of the KFOR force (Informacja nt. Polskiego... 2011). The reduction was to continue until the so-called deterrent presence was achieved. Since February 2010, KFOR has been comprised of five company-structured Multinational Battle Groups. It replaced the Multinational Task Force - East, becoming the Multinational Combat Group - East. The change in the structure of the stabilisation forces removed the sense of functioning of the common battalion in the mission area (Pismo Dowódcy Operacyjnego... 2010).

\section{Multinational Centre-South Division}

The second, equally important, joint undertaking carried out in the framework of the mission outside the borders was the participation of both countries in 
the international stabilisation operation in Iraq. Polish and Ukrainian soldiers cooperated there over the course of 2003-2005 in five subsequent turns of the Multinational Centre-South Division (MCSD, Polish - WDC-P). Apart from the political controversies related to the legal basis of intervention in Iraq, it should be recognised that the Ukrainian presence in the Polish sector of responsibility has expanded the existing dimension of political and military cooperation between the two countries.

In mid-April of 2003, the United States proposed that Poland should assume responsibility for one of the zones into which Iraq had been divided. Taking over the zone was connected with the formation of a multinational division with Poland in a leading role. The political decision was followed by conceptual and planning work and international negotiations on the allocation of forces and resources to the multinational military component. After the Polish-American consultations of May 5, 2003, it was decided that Poland would take control over the centralsouthern zone (Polski Kontyngent Wojskowy... 2011, pp. 20-21). The first result of the work related to the formation of the unit was the creation of the WDC-P command structure functioning in Poland.

Simultaneously with the creation of the command, negotiations were underway on the separation of national components into the divisions. The first undertaking dedicated to this goal was the participation of Polish observers in a conference on allocation of forces to join an international division under British command, which took place in London in April/May 2003 (Mathea 2004, p. 26). The next force generation conference took place in May 2003 in Warsaw (Przygotowanie operacji... 2018). During the conference, individual states declared the numbers of their contingents as follows: Poland -2200 , Ukraine -2000 , Fiji - 700, initially, Bulgaria - 500, Honduras - 360, Philippines - 300, Dominican Republic - 250 and Slovakia - 75 soldiers. In addition, it was proposed that officers be referred to the division command in the following numbers: Spain - up to 30, Denmark and Hungary -10 each, Netherlands -3 , Ukraine -2 and Bulgaria -1 . Following the Polish-Spanish consultations of June 2003, the Spanish side undertook to assign a component of 1300 soldiers. Additional technical arrangements with Spain completed the force generation process (Figure 6). The national components of the division were assigned by 20 countries, and 5 more states appointed further officers to strengthen its staff (Polski Kontyngent Wojskowy... 2011, p. 24). The 
largest contingents were deployed by: Poland, Ukraine and Spain. On their basis, three brigade battle groups Polish - BCT) were formed: 1 BCT - Poland, 2 BCT - Ukraine and 3 BCT - Spain. Proportionally, the contribution of these countries in terms of numbers was about $63 \%$ of the total soldiers in the division.

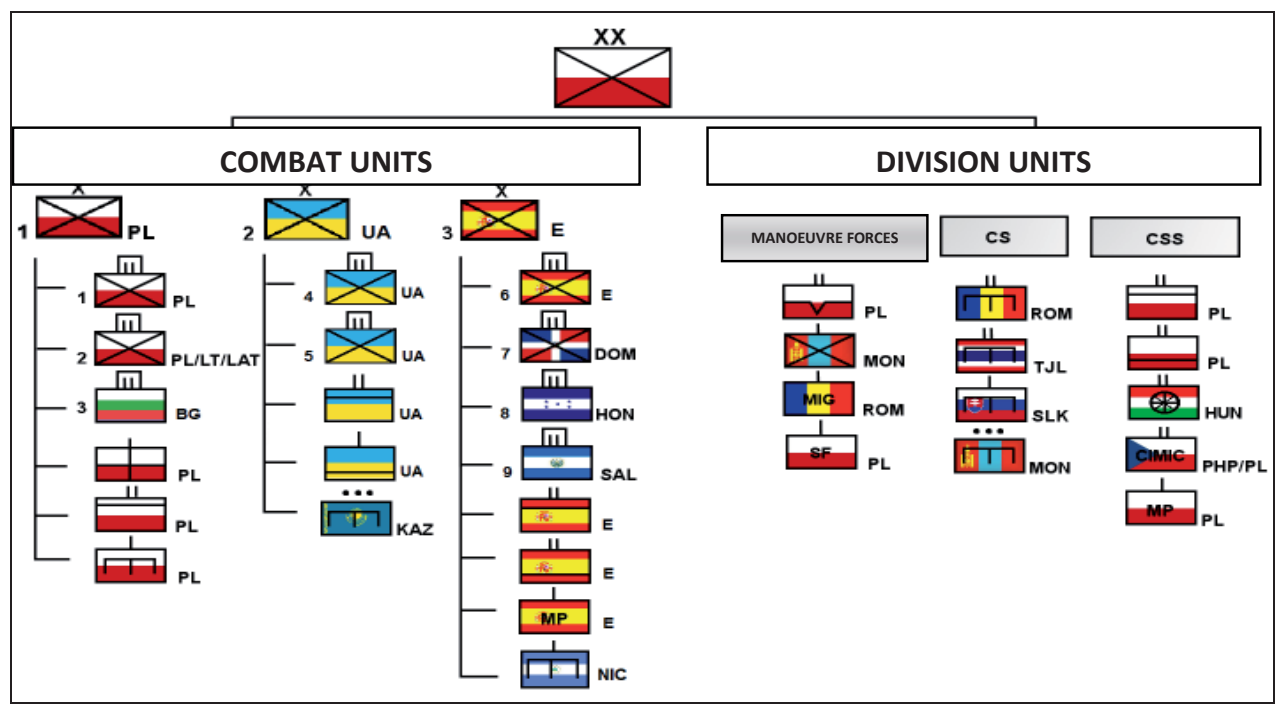

Source: Own studies based on: (Polski Kontyngent Wojskowy w Iraku 2003-2008 2011, pp. 24-50).

Figure 6. Organisational structure of Multinational Centre-South Division

The central-south zone under the responsibility of WDC-P covered five provinces: Al-Kadisija, An-Najaf, Babylon, Karbala and Wasit (Fig. 7) (Co każdy żotnierz... 2003, pp. 19-26). The area of responsibility included the two holy Shiite cities of An-Najaf and Karbala. Over 70\% of the total local population was concentrated in urban conurbations. Within the zone, there were small deposits of crude oil of low extraction importance. The operational area was very important in terms of the infrastructure located there. It was crossed by major transport routes, leading from the north to the south of the country, as well as by strategic gas and oil pipelines. The takeover of command of the zone took place on 3 September 2003. The division, after entering the operational area, was to carry out stabilisation activities in order to ensure conditions for reconstruction of the administration and economy of the region and to eliminate terrorist threats. In practice, the unit 
entering the theatre of activities carried out the offensive phase. These included offensive operations to deal with outbreaks of resistance and to neutralise the influence of terrorist organisations.

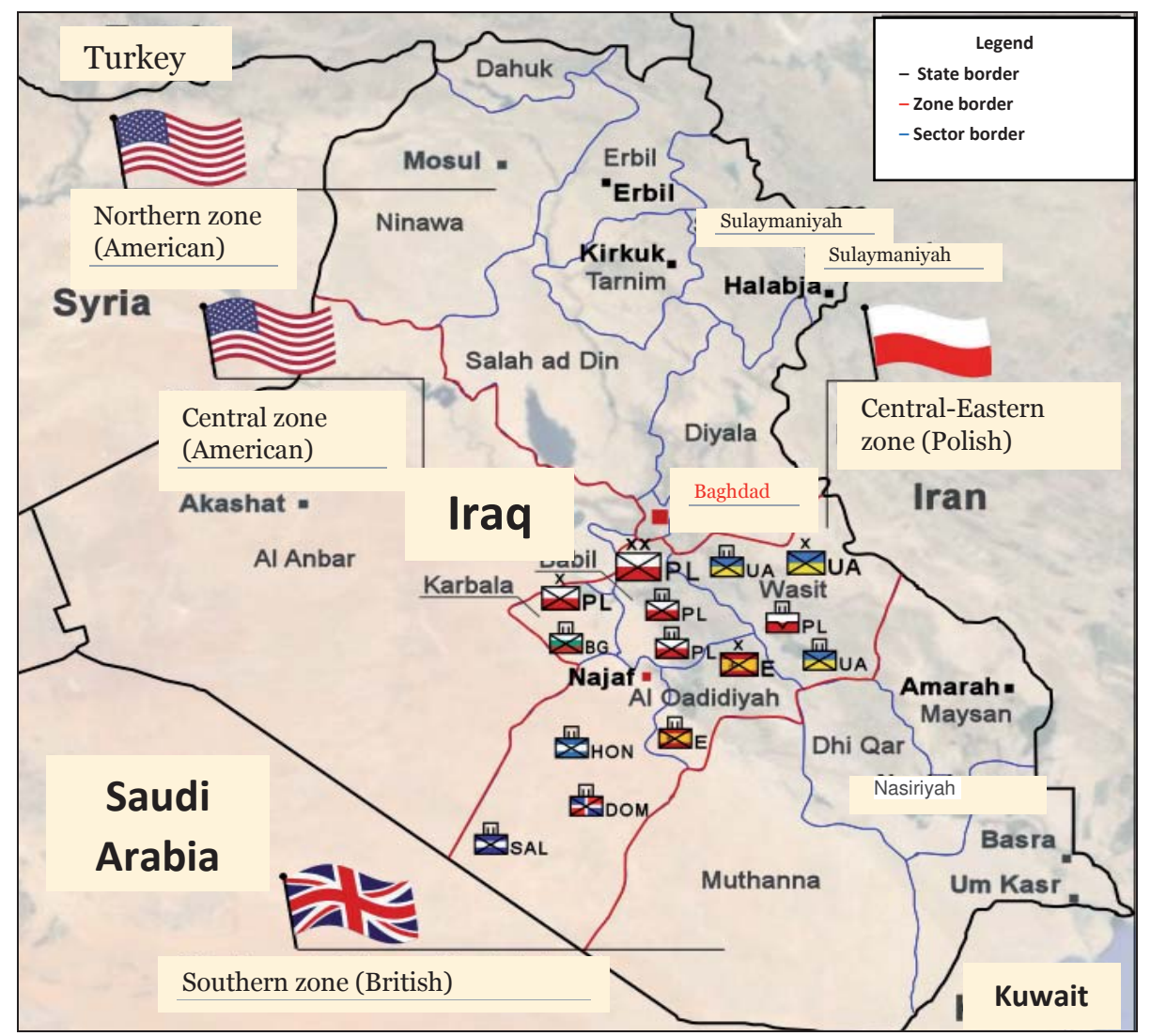

Source: Own study based on: (Polski Kontyngent Wojskowy w Iraku 2003-2008 2011, pp. 24-50).

Fig. 7. Deployment of Multinational Centre-South Division elements in Iraq

The first turn of WDC-P, serving from 3 September 2003 to 12 February 2004, consisted of three brigade battle teams: Polish, Ukrainian and Spanish, as well as the Independent Air and Assault Team (Polish). The total forces to be used in operations were: the Independent Air and Assault Team and nine battalion combat groups, Polish and Ukrainian, two each, as well as one each from: Bulgaria, the Dominican Republic, Spain, Honduras and El Salvador. Another turn, in service from 13 February to 17 July 2004, consisted, as the previous one, 
of three brigade combat teams and the Independent Air and Assault Team. In the course of the turn, the first reduction of the division's personnel took place (Polski Kontyngent Wojskowy... 2001, p. 76). Following the Madrid bombing, the Spanish government withdrew the 3rd Brigade Combat Team. In addition to Spain (on 18 April), national contingents were also withdrawn by Honduras (on 19 April) and the Dominican Republic (on 20 April). The size of the division decreased from 8200 soldiers and military personnel to approx. 6,500. The tasks performed by the second turn, apart from the transition to dynamic activities and pre-emptive actions, did not differ significantly from those of their predecessors (Lenart 2008, p. 77).

The structure of the third WDC-P turn, serving from 18 July 2004 to 31 January 2005, consisted of two brigade combat teams (Polish and Ukrainian) and the Independent Air and Assault Team. The brigade teams included a total of six battalion battle teams, Polish and Ukrainian, two each, as well as one each from Bulgaria and El Salvador. The tasks and basic forms of operating activity had not changed. In the course of the turn, there was another reduction of personnel (Polski Kontyngent Wojskowy...2011, p. 162). Further national contingents left Iraq: the Philippines (on 22 July 2004), Thai (on 23 August 2004), Hungarian (on 22 December 2004) and six Dutch staff officers (on 3 March 2005). On 21 January 2005, the division was joined by a 46-person contingent from Armenia. The next turn of WDC-P served from 1 February to 25 July 2005. It started its activities in the same structural and organisational composition as the previous turn. The personnel decreased on 7 May 2005, when Ukraine reduced its contingent. The type of operating activity did not change (Skrzypczak 2008, pp. 186-187).

The fifth WDC-P turn (from 26 July 2005 to 6 February 2006) consisted of two brigade battle teams and the Manoeuvre Team (Poland). The total forces intended for operational use consisted of: the Manoeuvre Team and five battalion combat teams, including two Ukrainian and one each from Bulgaria, Poland and El Salvador. In the course of the turn, another reduction in personnel was made. By the end of December 2005, Ukraine and Bulgaria had withdrawn their national contingents. During the turn, partially profiled tasks were completed. In operational terms, counter-terrorism activities with Iraqi forces were carried out jointly with new elements aimed at empowering local security structures. The non-operational tasks included training of armies and personnel and the creation, 
under the supervision of advisory and training teams, of units of the Iraqi army. These tasks reflected the shift in nature of the mission - becoming a training and stabilisation mission (Czerwiński 2006, pp. 17-18).

Ukrainian soldiers carried out tasks in Iraq in a slightly longer, seven-month cycle. During the five turns of WDC-P, Ukrainians rotated four times (Kolasiński 2008, pp. 259-261). The core of the contingents was made up of independent mechanised brigades (IMB, Polish -SBZ) and, at the end of the presence, the 81st Tactical Team (TT, Polish - 81 GT). The first turn of the contingent, based on the $5^{\text {th }}$ SBZ, began the mission in the Polish division on 11 August 2003. Another, whose main force was the 6th SBZ, took over the responsibility for the province of Wasit on 4 March 2004. The third turn (the 7th SBZ) carried out its tasks from 7 October 2004 to 6 May 2005. The reduced and the last, fourth turn of the Ukrainian contingent (81st GT) began its service on 7 May 2005.

The Polish-Ukrainian cooperation within WDC-P began with the first turn, with 2,389 and 1,640 soldiers assigned by each side respectively (Polski Kontyngent Wojskowy... 2001, p. 26). It was ended with the withdrawal of the Ukrainian contingent during the $5^{\text {th }}$ turn, in which the service was performed by 1,463 Polish and about 890 Ukrainian soldiers (Lenart 2008, p. 78). In terms of numbers, Ukraine allocated the second largest national contingent, on the basis of which the 2nd Brigade Combat Team was formed (in the last Ukrainian turn of 81 GT). During the next five turns, Ukrainians controlled the province of Wasit. The cooperation of Polish and Ukrainian soldiers at the tactical level ended on 19 December 2005, when the Ukrainian contingent ended its service within WDC-P (Polski Kontyngent Wojskowy...2011, p. 203). During the operation, 18 Ukrainians were killed and more than 40 were injured.

\section{Conclusions}

Military cooperation between the Armed Forces of the Republic of Poland and Ukraine is an important element of mutual contacts between the states. However, political declarations and the constant will to cooperate were not always fully translated into practical actions. The accession of both countries to the Partnership for Peace programme and the formation of a joint battalion have dramatically 
increased its scope. In practical terms, the main part of the cooperation was related to the operation of joint military units and the training of national contingents for peacekeeping missions (Kosovo and Iraq).

The prospect of joining NATO and the launch of the Partnership for Peace programme contributed to the formation of multinational subdivisions, including the Polish-Ukrainian ones. Political will and the determination of the highest authorities of the state became a factor which contributed to overcoming difficulties of formal and legal nature. The formation and subsequent training of a joint battalion provided the experience needed for further reshaping of the armed forces of both countries. The political success associated with the establishment of POLUKRBAT and the high evaluation of its usefulness created the conditions for extending this form of cooperation. Joint Polish-Ukrainian units, in the following sequence: POLUKRBAT, LITPOLUKRBAT (only at the conceptual stage) and LITPOLUKBRIG have brought Ukraine significantly closer to the North Atlantic Alliance.

Until 2000, Poland and Ukraine had participated autonomously in peacekeeping missions under the auspices of international organisations. Since 2000, peacekeeping and stabilisation missions have become one of the most important directions of their military cooperation. This has been demonstrated by the strength and resources that both countries have chosen to devote to it. The attention paid by the partners to cooperation in this field was underlined by the decision to set up joint military structures dedicated to this task. The cooperation between the Polish and Ukrainian subdivisions was of a long-term nature, and the level of projects implemented by them was appreciated and highly praised by their superiors.

\section{References}

21 Brygada Strzelców Podhalańskich. [online] Available from: www.21bsp.wp.mil.pl [Accessed 17 Mar 2018].

89. posiedzenie Sejmu. [online] Available from: http://www.sejm.gov.pl/sejm7.nsf/ komunikat [Accessed 18 Mar 2018].

Adamski, Ł., 2010. Polityka Polski wobec Ukrainy, Rocznik Polskiej Polityki Zagranicznej. 
Brygada Litewsko - Polsko - Ukraińska (LITPOLUKRBRIG), Załącznik do Pisma Zastępcy Dyrektora Sekretariatu Ministra Obrony Narodowej w sprawie materiałów na Konsultacje Wysokiego Szczebla NATO - Ukraina oraz spotkania Ministrów Obrony UE w formule GAERC (Bruksela, 16-17 listopada br.) of 29 October 2009, DWSZ MON, unpublished.

Brygada międzynarodowa sygnatem dla wszystkich, [online] Available from: http://lublin. gosc.pl/doc/2943542.Brygada-miedzynarodowa-sygnalem-dla-wszystkich [Accessed 19 Mar 2018].

Chojnowska, A., 1996. Stosunki z Ukrainą. Rocznik Polskiej Polityki Zagranicznej. Chojnowska, A., 1997. Stosunki z Ukrainą. Rocznik Polskiej Polityki Zagranicznej. Cieślik, M., 1999. Stosunki z Ukrainą. Rocznik Polskiej Polityki Zagranicznej.

Co każdy żotnierz wiedzieć powinien? Vademecum dla żotnierzy przygotowujacych się do realizacji zadań $w$ ramach misji stabilizacyjnej $w$ Iraku, 2003. Dowództwo Wojsk Lądowych, Warszawa.

Czerwiński, P., 2006. Piąta zmiana PKW Irak - zadania, działalność i wnioski. In J. Gotowała (ed.), Irak 2006 - osłona młodej demokracji. Materiat z konferencji naukowej, Wydawnictwo Naukowe AON, Warszawa.

Drzewicki, A., 2008. Polsko-ukraińska współpraca wojskowa w świetle umów i porozumień dwustronnych. In M. Wolański and Ł. Leszczenko (eds), Ze studiów polsko-ukraińskich, Oficyna Wydawnicza Arboretum, Wrocław.

Drzewicki, A., 2011. Stosunki z Ukrainą w sferze bezpieczeństwa: polski punkt widzenia. Bezpieczeństwo Narodowe, 17.

Informacja na temat przedsięwzięć realizowanych ze strona ukrainska w 2007 roku w ramach działalności kompetencyjnej Zarzadu Planowania Operacyjnego - P3, Załącznik nr 1 do pisma Szefa Zarządu Operacyjnego P3 z 18 kwietnia 2008 r. w sprawie: Przygotowania materiałów informacyjnych na spotkanie z Szefem Sztabu Głównego SZ Ukrainy, AMON, ref. 2840/11/7.

Informacja nt. Polskiego Kontyngentu Wojskowego w Siłach Międzynarodowych w Kosowie (PKW KFOR), 12 January 2011. DWSZ MON, unpublished.

Informacja nt. tworzenia litewsko-polsko-ukraińskiego batalionu (LITPOLUKRBAT), 12 December 2007. DWSZ MON, Warszawa, unpublished.

Informacja nt. udziału Polskiego Kontyngentu Wojskowego w Siłach Międzynarodowych w Kosowie (KFOR), 2004. DWSZ MON, unpublished.

Kochanowski, F., 2000. Udział Wojska Polskiego w misjach pokojowych w latach dziewięćdziesiątych. Rocznik Polskiej Polityki Zagranicznej.

Kolasiński, M., 2008. Udział Ukrainy w stabilizacji postsaddamowskiego Iraku. In J. Marszałek-Kawa and Z. Karpus (ed.), Stosunki polsko-ukraińskie. Wojna i współczesność, Wydawnictwo Adam Marszałek, Toruń.

Koncepcja dalszego zaangażowania PKW KFOR w operacji w Kosowie, 2006. Dowództwo Operacyjne DWSZ MON, unpublished. 
Kronika stosunków międzynarodowych Polski. Ukraina, 1999. Rocznik Polskiej Polityki Zagranicznej.

Lenart, P., 2008. Zaangażowanie Sił Zbrojnych Rzeczypospolitej Polskiej w operacji stabilizacyjnej w Iraku w latach 2003-2008. Zeszyty Naukowe AON, 3A.

List intencyjny w sprawie wspólnej litewsko-polsko-ukraińskiej brygady. [online] Available from: www.money.pl [Accessed 20 Mar 2018].

LITPOLBRIG. Historia, [online] Available from: http://litpolukrbrig.wp.mil.pl/pl/111. html [Accessed 22 Mar 2018]

LITPOLUKRBRIG. Jednostki afiliowane. [online] Available from: http://litpolukrbrig. wp.mil.pl/pl/114.html [Accessed 25 Mar 2018].

LITPOLUKRBRIG. Struktura. [online] Available from: http://litpolukrbrig.wp.mil.pl/ pl/108.html [Accessed 25 Mar 2018].

LITPOLUKRBRIG. Szkolenie, [online] Available from: http://litpolukrbrig.wp.mil.pl/ pl/110.html [Accessed 27 Mar 2018].

Mathea, T., 2004. Pierwsza zmiana - początek drogi. Dobór, typowanie, przygotowanie jednostek i żołnierzy. Operacja gromadzenia sił i środków w rejonie realizacji misji. In J. Gotowała (ed.), Trudna stabilizacja. Materiał z konferencji naukowej zorganizowanej z inicjatywy i pod patronatem Ministra Obrony Narodowej, Warsaw.

MEMORANDUM w sprawie rozszerzenia wspótpracy między Ministerstwem Obrony Narodowej Rzeczypospolitej Polskiej i Ministrem Obrony Ukrainy w zakresie udziału w międzynarodowych misjach pokojowych. Załącznik do Pisma Dyrektora Sekretariatu MON, 10 April 2000. DWSZ MON, Warsaw, unpublished.

Meszka, A., Stosunki polsko-ukraińskie w latach 1989-2004, p. 10, [online] Available from: www.stosunki-miedzynarodowe.pl [Accessed 24 Mar 2018].

Nawrot, M., 2001. Udział Polski w Pakcie Stabilności dla Europy Południowo-Wschodniej. Rocznik Polskiej Polityki Zagranicznej.

Notatka Dyrektora Departamentu Prawnego MON w sprawie stanu prac nad projektem umowy między rzadami RP $i$ Ukrainy w sprawie utworzenia wspólnej jednostki wojskowej, 26 August 1997. AMON, ref. 2026/03/95.

Notatka w sprawie listu SACEUR-a dotyczacego zmian struktury sit KFOR, 21 March 2006. AMON, ref. 3018/13/9.

Notatka $z$ wizyty delegacji Ministra Obrony Narodowej na Ukrainie w dn. 1-3.02.1993 r., AMON, ref. 2093/03/27.

Notatka $z$ wizyty POW $w$ KOW $w$ dniach 22-24 czerwca 1994 r., AMON, ref. $1668 / 2000 / 7$.

Pismo Dowódcy Operacyjnego Sit Zbrojnych w sprawie dalszego udziału SZ RP w misji w Kosowie. 21 January 2010. DWSZ MON, unpublished.

Pismo Dyrektora Departamentu Wojskowych Spraw Zagranicznych w sprawie polskoukraińskiego batalionu sit pokojowych. 10 March 1997. AMON, ref. 2111/03/17. 
Pismo Szefa Generalnego Zarzadu Operacyjnego - P3 w sprawie listu SACEURA-a w sprawie zmian struktury KFOR. 15 March 2006. AMON, ref. 3018/13/9.

Pismo Szefa Zarzadu Planowania Operacyjnego P-3 w sprawie wspótpracy wojskowej w ramach państw Grupy Wyszehradzkiej oraz z Ukraina. 15 June 2010. AMON, ref. 2399/09/58.

PKW w sktadzie polsko-ukraińskiego batalionu w siłach międzynarodowych $w$ Kosowie.

26 September 2000. PKW Kosowo, DWSZ MON, unpublished.

Polski Kontyngent Wojskowy w Iraku 2003-2008, 2011. Kronika Wojska Polskiego.

Polsko-Ukrainski Batalion Sit Pokojowych. [online] Available from: www.mon.gov.pl

[Accessed 27 Mar 2018].

POLUKRBAT - Polsko-Ukraiński Batalion Sit Pokojowych. [online]. Available from: www. stosunki-miedzynarodowe.pl [Accessed 27 Mar 2018].

Porozumienie między Ministrem Obrony Narodowej Rzeczypospolitej Polskiej a Ministrem

Obrony Ukrainy o wspótpracy w dziedzinie wojskowej. Podpisano w Kijowie 3 lutego 1993 r. w dwóch wersjach językowych: polskiej i ukraińskiej, Departament Wojskowych Spraw Zagranicznych Ministerstwa Obrony Narodowej, DWSZ MON, unpublished. Porozumienie techniczne między Ministerstwem Obrony Narodowej Republiki Litewskiej,

Ministrem Obrony Narodowej Rzeczypospolitej Polskiej i Ministerstwem Obrony Ukrainy $w$ sprawie szczegótowych aspektów funkcjonowania wspólnej jednostki wojskowej i jej dowództwa. sporządzone we Lwowie dnia 24 lipca 2015 r., Journal of Laws of 2015, No. 0, item 1291.

Prezydent podpisat ustawę dot. sformowania litewsko-polsko-ukraińskiej brygady. [online] Available from: https://www.bbn.gov.pl/pl/wydarzenia/6677,Prezydent-Swiatzachodni-nie-moze-zatrzasnac-drzwi-przed-Ukraina.html [Accessed 22 Mar 2018].

Projekt Koncepcji utworzenia brygady litewsko - polsko - ukraińskiej. Pismo I Zastępcy Szefa Sztabu Generalnego WP, 4 June 2009 r., DWSZ MON, unpublished.

Przygotowanie operacji. [online] Available from: www.pkwirak.wp.mil.pl [Accessed 17 Mar 2018].

Skrzypczak, W., 2008. Wspomnienia i refleksje dowódców Wielonarodowej Dywizji Centrum-Południe. Zeszyty Naukowe AON, 3A.

Sprawozdanie z przebiegu wizyty dowództwa Krakowskiego Okręgu Wojskowego w dowództwie Przykarpackiego Okręgu Wojskowego. Załącznik nr 1 do pisma Szefa Oddziału Kontaktów Zagranicznych SG of 7 March 1996, AMON, ref. 2027/03/3.

Sprawozdanie z wizyty dowództwa Krakowskiego Okręgu Wojskowego w Dowództwie Przykarpackiego Okręgu wojskowego w dniach 8-10 lipca 1996 r. AMON, ref. 2027/03/3.

Stan prac nad polsko-ukraińskim batalionem do misji pokojowych ONZ. Załącznik do pisma Szefa Oddziału Kontaktów Zagranicznych SG z 26 marca 1996 r. w sprawie informacji nt. polsko-ukraińskiego batalionu do misji pokojowych ONZ, AMON, ref. 2027/03/6. 
Stowarzyszenie Kombatantów Misji Pokojowych ONZ. [online] Available from: www. skmponz.szczecin.pl [Accessed 27 Mar 2018].

Szmyd, Z., 2000. Stosunki z Ukrainą, Rocznik Polskiej Polityki Zagranicznej.

Szumski, A., 2008. Polsko-ukraińska współpraca wojskowa na przykładzie PolskoUkraińskiego Batalionu Sił Pokojowych (POLUKRBAT). In M. Wolański and Ł. Leszczenko (ed.), Ze studiów polsko-ukraińskich, Oficyna Wydawnicza Arboretum, Wrocław.

Tezy na spotkanie ministrów obrony Polski i Ukrainy w dniach 26-28 listopada 1997 r. $w$ Warszawie. Pion Wiceministra Obrony Narodowej RPds. Polityki Obronnej, AMON, ref. 2111/03/17.

Uchwata Nr 17/99 Rady Ministrów z dnia 16 lutego 1999 r. w sprawie ratyfikacji Umowy międzynarodowej między Rzeczypospolita Polska a Ukraing w sprawie utworzenia wspólnej jednostki wojskowej do udziatu w międzynarodowych operacjach pokojowych $i$ humanitarnych pod egida międzynarodowych organizacji. DWSZ MON, unpublished.

Umowa między Rzeczpospolita Polską a Ukraing w sprawie utworzenia wspólnej jednostki wojskowej do udziału w międzynarodowych operacjach pokojowych i humanitarnych pod egida międzynarodowych organizacji podpisana $w$ Warszawie w dniu 26 listopada 1997 r. Journal of Laws of 2003, No. 78, item 692.

Wielonarodowa Brygada (cz. polska). [online] Available from: http://wb.wp.mil.pl/pl/79. html [Accessed 27 Mar 2018].

Wspólna brygada Polski, Litwy i Ukrainy coraz bliżej powstania. [online] Available from: http://www.polska-zbrojna.pl/home/articleshow/16681?t=Wspolna-brygada-PolskiLitwy-i-Ukrainy-coraz-blizej-powstania [Accessed 17 Mar 2018]. 